\title{
Introductory Chapter: A Brief Overview of Transcriptional and Post-transcriptional Regulation
}

\author{
Kais Ghedira \\ Additional information is available at the end of the chapter \\ http://dx.doi.org/10.5772/intechopen.79753
}

\section{Prologue}

The regulation of gene expression is the process by which expression of genes is controlled (induced or repressed) at the cell level in a particular time under a particular condition. It is a fundamental process to diverse other biological processes that occur within the cell including cell development and differentiation, the response and the adaptation to environmental stresses. Gene regulation has classically been viewed as the interaction between proteins to regulatory elements located at the vicinity of the transcription start site within promoters. However, gene regulation is a more complex process that involves additional layers of control including chromatin remodeling, nucleosome positioning, histone modifications, DNAbinding regulatory proteins such as transcription factors and noncoding RNA [1-3]. Such process requires structural and chemical changes to the genetic material, binding of proteins to specific DNA elements to regulate transcription, or mechanisms that modulate translation of mRNA.

Indeed, gene expression is controlled at multiple cellular levels consisting in the chromatin level through chromatin modification and remodeling, the mRNA level (transcriptional and posttranscriptional regulation) and protein level (translation regulation and posttranslational degradation).

This introductory chapter will give a brief overview on the transcriptional and posttranscriptional regulation, list the main database resources that can be used for transcriptional and/or posttranscriptional regulation data and finally list the main tools allowing to predict TF and miRNA gene targets. 


\section{Transcriptional regulation}

Regulation at the transcriptional level involves proteins called transcription factors (TFs) that recognize and bind specifically to regulatory elements within the promoter regions to control the expression of a downstream gene. These TFs regulate target genes - by turning them on and off-in order to make sure that they are transcribed into mRNA within the cell at the right time and in the right amount. TFs are classified into three large families of DNA-binding domains that include:

1. Basic helix-loop-helix (bHLH) proteins found in organisms from yeast to humans and function in critical developmental processes controlling embryonic development, particularly in neurogenesis, myogenesis, heart development, and hematopoiesis [4, 5].

2. The TFs with basic leucine zipper domains [6].

3. TFs with the helix-turn-helix $(\mathrm{HTH})$ domains that are involved in a wide range of functions beyond transcription regulation, including DNA repair and replication, RNA metabolism, and protein-protein interactions in diverse signaling contexts $[7,8]$. This group also includes homeobox (zinc finger, HOX-like, TALE, POU, etc.) and homeodomain protein products.

High-throughput techniques including ChIP-on-chip/ChIP-seq and enhanced yeast onehybrid have been widely employed to uncover protein-DNA interactions $[9,10]$ and represent convenient methods to identify and characterize the repertoire of regulatory elements that can be targeted by a protein of interest or transcription factors that can bind a DNA sequence of interest [11], respectively. Thanks to the ENCODE (Encyclopedia of DNA Elements) project aiming to build a comprehensive parts list of functional elements in the human genome including regulatory elements that control cells, such regulatory data were made available for the scientific community (https://www.encodeproject.org/; http://genome.ucsc.edu/encode/ downloads.html) [12] and led to largely improve our understanding of gene regulation.

In addition to the ENCODE project, several regulatory databases have been developed for including multiple animals/plants/microorganisms regulation data. Table 1 lists the most widely used transcriptional regulation database with a brief description, reference to original publication and current accessible website URL.

\begin{tabular}{|c|c|c|c|c|}
\hline Database & Acronym & Website link & Description & References \\
\hline TRANSFAC & TRANSFAC & $\begin{array}{l}\text { http://genexplain. } \\
\text { com/transfac/ }\end{array}$ & $\begin{array}{l}\text { TRANSFAC } ® \text { is a maintained and } \\
\text { curated database of eukaryotic } \\
\text { transcription factors, their genomic } \\
\text { binding sites, and DNA-binding } \\
\text { profiles. }\end{array}$ & [13] \\
\hline $\begin{array}{l}\text { Transcription Regulatory } \\
\text { Regions database }\end{array}$ & TRRD & $\begin{array}{l}\text { http://wwwmgs. } \\
\text { bionet.nsc.ru/mgs/ } \\
\text { gnw/trrd/ }\end{array}$ & $\begin{array}{l}\text { TRRD is a unique information } \\
\text { resource, accumulating information } \\
\text { on the structural and functional } \\
\text { organization of transcription } \\
\text { regulatory regions of eukaryotic } \\
\text { genes. }\end{array}$ & {$[14]$} \\
\hline Ensembl Regulation & $\begin{array}{l}\text { Ensembl } \\
\text { Regulation }\end{array}$ & $\begin{array}{l}\text { https://www. } \\
\text { ensembl.org/info/ }\end{array}$ & $\begin{array}{l}\text { Ensembl Regulation provides } \\
\text { resources used for studying gene }\end{array}$ & {$[15]$} \\
\hline
\end{tabular}




\begin{tabular}{|c|c|c|c|c|}
\hline Database & Acronym & Website link & Description & References \\
\hline & & $\begin{array}{l}\text { genome/funcgen/ } \\
\text { index.html }\end{array}$ & $\begin{array}{l}\text { expression and its regulation in } \\
\text { human and mouse, with a focus on } \\
\text { the transcriptional and } \\
\text { posttranscriptional mechanisms. }\end{array}$ & \\
\hline $\begin{array}{l}\text { Regulatory Network } \\
\text { Repository of Transcription } \\
\text { Factor and microRNA } \\
\text { Mediated Gene Regulations }\end{array}$ & RegNetwork & $\begin{array}{l}\text { http://www. } \\
\text { regnetworkweb. } \\
\text { org/source.jsp }\end{array}$ & $\begin{array}{l}\text { RegNetwork is developed based on } \\
25 \text { databases that provide the } \\
\text { regulatory relationship information, } \\
\text { annotation, and other necessary } \\
\text { information in order to derive the } \\
\text { regulatory relationships. }\end{array}$ & [16] \\
\hline $\begin{array}{l}\text { Transcriptional Regulatory } \\
\text { Element Database }\end{array}$ & TRED & $\begin{array}{l}\text { http://rulai.cshl. } \\
\text { edu/TRED/ }\end{array}$ & $\begin{array}{l}\text { TRED provides good training } \\
\text { datasets for further genome-wide cis- } \\
\text { regulatory element prediction, assist } \\
\text { detailed functional studies, and } \\
\text { facilitate to decipher the gene } \\
\text { regulatory networks. }\end{array}$ & [17] \\
\hline $\begin{array}{l}\text { Transcriptional Regulatory } \\
\text { Relationships Unraveled by } \\
\text { Sentence Based Text mining }\end{array}$ & TRRUST & $\begin{array}{l}\text { http://www. } \\
\text { grnpedia.org/ } \\
\text { trrust/ }\end{array}$ & $\begin{array}{l}\text { TRRUST database provides } \\
\text { information of mode of regulation } \\
\text { (activation or repression). }\end{array}$ & [18] \\
\hline $\begin{array}{l}\text { Open Regulatory Annotation } \\
\text { database }\end{array}$ & ORegAnno & $\begin{array}{l}\text { http://www. } \\
\text { oreganno.org/ }\end{array}$ & $\begin{array}{l}\text { The Open Regulatory Annotation } \\
\text { database (ORegAnno) is a resource } \\
\text { for curated regulatory annotation. }\end{array}$ & [19] \\
\hline PRODORIC & PRODORIC2 & $\begin{array}{l}\text { http://www. } \\
\text { prodoric2.de }\end{array}$ & $\begin{array}{l}\text { The PRODORIC } 2 \text { database hosts one } \\
\text { of the largest collections of DNA- } \\
\text { binding sites for prokaryotic } \\
\text { transcription factors. }\end{array}$ & [20] \\
\hline $\begin{array}{l}\text { Gene Transcription Regulation } \\
\text { Database }\end{array}$ & GTRD & $\begin{array}{l}\text { http://gtrd.biouml. } \\
\text { org/ }\end{array}$ & $\begin{array}{l}\text { The most complete collection of } \\
\text { uniformly processed ChIP-seq data to } \\
\text { identify transcription factor binding } \\
\text { sites for human and mouse. }\end{array}$ & [21] \\
\hline $\begin{array}{l}\text { Transcription factor prediction } \\
\text { database }\end{array}$ & DBD & $\begin{array}{l}\text { http://www. } \\
\text { transcriptionfactor. } \\
\text { org/index.cgi? } \\
\text { Home }\end{array}$ & $\begin{array}{l}\text { DBD is a database of predicted } \\
\text { transcription factors in completely } \\
\text { sequenced genomes. }\end{array}$ & [22] \\
\hline
\end{tabular}

Acronyms in bold letters denote curated databases.

Table 1. Eukaryotic and prokaryotic regulation databases.

\section{Post-transcriptional regulation}

A very large part of the human genome constitutes noncoding elements classified as small noncoding RNAs (sncRNAs) and long noncoding RNAs (lncRNAs). These noncoding components are receiving increased attention from researchers due to their predicted important role in posttranscriptional regulation. Small ncRNAs class includes small interfering RNAs (siRNAs), microRNAs (miRNAs), PIWI-interacting RNAs (piRNAs), endogenous small interfering RNAs (endo-siRNAs or esiRNAs), promoter associate RNAs (pRNAs), small nucleolar RNAs (snoRNAs), and sno-derived RNAs, while lncRNAs includes linc RNA, NAT, eRNA, 
circ RNA, ceRNAs, PROMPTS. Both lncRNAs and sncRNAs have been identified at regulatory elements [23, 24]. Among these noncoding elements, microRNAs have been the most widely investigated since their discovery in the early 1990s, underscoring their importance in posttranscriptional gene regulation [25]. These later act as posttranscriptional regulators of their messenger RNA (mRNA) targets via mRNA degradation and/or translational repression [26]. It has been widely evidenced that miRNA-mediated downregulation is a one-way process leading to the repression of translation and/or target mRNA degradation [27-30]; however, recent studies have shown that miRNAs are able to upregulate gene expression in specific cell types and conditions with distinct transcripts and proteins [31].

Pulling down microRNA-induced silencing complexes (miRISCs) immunoprecipitation method allows researchers to collect information on microRNAs and their mRNA targets in vivo. Such information has been collected and stored in several public databases. Table 2 contains the most widely used posttranscriptional regulation database with a brief description, reference to original publication and current functional website URL.

\begin{tabular}{|c|c|c|c|c|}
\hline Database & Acronym & Website link & Description & References \\
\hline The microRNA database & miRBase & $\begin{array}{l}\text { http://www. } \\
\text { mirbase.org/ }\end{array}$ & $\begin{array}{l}\text { The miRBase database is a searchable } \\
\text { database of published miRNA sequences } \\
\text { and annotation. }\end{array}$ & {$[32]$} \\
\hline $\begin{array}{l}\text { The experimentally } \\
\text { validated microRNA- } \\
\text { target interactions } \\
\text { database }\end{array}$ & miRTarBase & $\begin{array}{l}\text { http://mirtarbase. } \\
\text { mbc.nctu.edu.tw/ } \\
\text { php/index.php }\end{array}$ & $\begin{array}{l}\text { miRTarBase has accumulated miRNA- } \\
\text { target interactions (MTIs), which are } \\
\text { collected by manually surveying pertinent } \\
\text { literature. }\end{array}$ & {$[33]$} \\
\hline miRDB & miRDB & $\begin{array}{l}\text { http://mirdb.org/ } \\
\text { miRDB/ }\end{array}$ & $\begin{array}{l}\text { miRDB is an online database for miRNA } \\
\text { target prediction and functional } \\
\text { annotations }\end{array}$ & {$[34]$} \\
\hline miRNAMap & miRNAMap & $\begin{array}{l}\text { http://mirnamap. } \\
\text { mbc.nctu.edu.tw/ }\end{array}$ & $\begin{array}{l}\text { An online resource that stores information } \\
\text { related to the known miRNAs in metazoan. }\end{array}$ & {$[35]$} \\
\hline Vir-Mir & Vir-Mir & $\begin{array}{l}\text { http://alk.ibms. } \\
\text { sinica.edu.tw/cgi- } \\
\text { bin/miRNA/ } \\
\text { miRNA.cgi }\end{array}$ & $\begin{array}{l}\text { Contains predicted viral miRNA candidate } \\
\text { hairpins }\end{array}$ & {$[36]$} \\
\hline Virus miRNA Target & ViTA & $\begin{array}{l}\text { http://vita.mbc.nctu. } \\
\text { edu.tw/ }\end{array}$ & $\begin{array}{l}\text { ViTa collects virus data from miRBase and } \\
\text { ICTV, VirGne, VBRC, etc. and provide } \\
\text { effective annotations, including human } \\
\text { miRNA expression, virus-infected tissues, } \\
\text { annotation of virus, and comparisons. }\end{array}$ & [37] \\
\hline miRecords & miRecords & $\begin{array}{l}\text { http://c1. } \\
\text { accurascience.com/ } \\
\text { miRecords/ }\end{array}$ & $\begin{array}{l}\text { miRecords is a resource for animal miRNA- } \\
\text { target interactions. }\end{array}$ & {$[38]$} \\
\hline $\begin{array}{l}\text { microRNA Data } \\
\text { Integration Portal }\end{array}$ & mirDIP & $\begin{array}{l}\text { http://ophid. } \\
\text { utoronto.ca/mirDIP/ }\end{array}$ & $\begin{array}{l}\text { Provides several million human } \\
\text { microRNA-target predictions, which were } \\
\text { collected across } 30 \text { different resources. }\end{array}$ & [39] \\
\hline
\end{tabular}

Acronyms in bold letters denote curated databases.

Table 2. Eukaryotic and prokaryotic posttranscriptional regulation databases. 


\section{The interplay between TFs and miRNAs}

Transcription factors (TFs) and microRNAs (miRNAs) are key regulators of gene expression. Several studies have shown that abnormal miRNA and/or TF expression can be critical for cell survival and development through targeting critical genes in the cellular system. In the last decade, several bioinformatic studies have been performed to elucidate transcriptional and posttranscriptional (mostly miRNA-mediated) regulatory interactions. Besides experimental techniques (ChIP-Seq, ChIP-ChIP, yeast two-hybrid, miRISCs), computational tools have been developed to predict the TF-gene target and/or miRNA-target interactions. Table 3 lists some bioinformatic tools used to predict transcriptional and posttranscriptional regulation. Using such tools and/or through the integration of data collected from public databases (Tables 1 and 2), researchers were able to generate regulatory networks aiming to understand mechanisms involved in some phenotypes and/or diseases. Recent studies focused on the study of mixed miRNA/TF feed-forward regulatory loops (FFLs) through genome-wide transcriptional and posttranscriptional regulatory network integration to decipher the complex and interlinked cascade of events related to several diseases [46-48]. Such approaches provide the scientific community with the ability to investigate the interplay between TFs and miRNAs in a given system.

\begin{tabular}{|c|c|c|c|}
\hline Tool/Web tool & Website link & Description & References \\
\hline \multicolumn{4}{|l|}{ TF-target prediction } \\
\hline TargetFinder & http://targetfinder.org/ & $\begin{array}{l}\text { Provides a web-based resource for finding genes that } \\
\text { show a similar expression pattern to a group of user- } \\
\text { selected genes. }\end{array}$ & {$[40]$} \\
\hline $\begin{array}{l}\text { BART: Binding analysis } \\
\text { for regulation of } \\
\text { transcription }\end{array}$ & $\begin{array}{l}\text { http://faculty.virginia. } \\
\text { edu/zanglab/bart/ }\end{array}$ & $\begin{array}{l}\text { A novel computational method and software package } \\
\text { for predicting functional transcription factors that } \\
\text { regulate a query gene set or associate with a query } \\
\text { genomic profile, based on more than } 6000 \text { existing } \\
\text { ChIP-seq datasets for over } 400 \text { factors in human or } \\
\text { mouse. }\end{array}$ & [41] \\
\hline MATCH & $\begin{array}{l}\text { http://gene-regulation. } \\
\text { com/pub/programs. } \\
\text { html\#match }\end{array}$ & $\begin{array}{l}\text { Match is a weight matrix-based program for } \\
\text { predicting transcription factor binding sites (TFBS) in } \\
\text { DNA sequences. }\end{array}$ & {$[42]$} \\
\hline \multicolumn{4}{|l|}{ MiRNA-target prediction } \\
\hline RNAhybrid & $\begin{array}{l}\text { https://bibiserv. } \\
\text { cebitec.uni-bielefeld.de/ } \\
\text { rnahybrid/ }\end{array}$ & $\begin{array}{l}\text { RNAhybrid is a tool for finding the minimum free } \\
\text { energy hybridization of a long and a short RNA. }\end{array}$ & [43] \\
\hline TargetScan & $\begin{array}{l}\text { http://www.targetscan. } \\
\text { org/vert_72/ }\end{array}$ & $\begin{array}{l}\text { TargetScan predicts biological targets of miRNAs by } \\
\text { searching for the presence of conserved } 8 \text { mer, } 7 \text { mer, } \\
\text { and } 6 \text { mer sites that match the seed region of each } \\
\text { miRNA. }\end{array}$ & {$[44]$} \\
\hline miRWalk & $\begin{array}{l}\text { http://zmf.umm.uni- } \\
\text { heidelberg.de/apps/zmf/ } \\
\text { mirwalk2/ }\end{array}$ & $\begin{array}{l}\text { Supplying the biggest available collection of predicted } \\
\text { and experimentally verified miRNA-target } \\
\text { interactions with various novel and unique features. }\end{array}$ & {$[45]$} \\
\hline
\end{tabular}

Table 3. TF and miRNA target prediction tools. 


\section{Conclusion}

During these last years, transcriptional and posttranscriptional regulation constituted the most important layers of gene regulation. However, a recent study by Barna group [49] has upset our understanding of gene regulation. Indeed, while researchers have believed for decades that ribosomes are identical showing no preference for translating RNA molecules into proteins, it appears that these later exhibit a preference for translating certain types of genes. One type of ribosome, for example, prefers to translate genes involved in cellular differentiation, while another specializes in genes that carry out essential metabolic duties. This study is uncovering a new layer of gene expression regulation that will have broad implications for basic science and human disease.

\section{Author details}

Kais Ghedira

Address all correspondence to: kais.ghedira@pasteur.rns.tn

Laboratory of Bioinformatics, Biomathematics and Biostatistics, Institut Pasteur de Tunis, University of Tunis El-Manar, Tunis, Tunisia

\section{References}

[1] Venters BJ, Pugh BF. How eukaryotic genes are transcribed. Critical Reviews in Biochemistry and Molecular Biology. 2009;44:117-141

[2] Mercer TR, Dinger ME, Mattick JS. Long non-coding RNAs: Insights into functions. Nature Reviews. Genetics. 2009;10:155-159

[3] Goodrich JA, Kugel JF. Non-coding-RNA regulators of RNA polymerase II transcription. Nature Reviews. Molecular Cell Biology. 2006;7:612-616

[4] Littlewood TD, Evan GI. Transcription factors 2: Helix-loop-helix. Protein Profile. 1995; 2(6):621-702. PMID 7553065

[5] Jones S. An overview of the basic helix-loop-helix proteins. Genome Biology. 2004;5(6): 226. Epub 2004 May 28. Review. PubMed PMID: 15186484; PubMed Central PMCID: PMC463060

[6] Vinson C, Myakishev M, Acharya A, Mir AA, Moll JR, Bonovich M. Classification of human B-ZIP proteins based on dimerization properties. Molecular and Cellular Biology. 2002;22(18):6321-6335. DOI: 10.1128/MCB.22.18.6321-6335.2002. PMC 135624. PMID 12192032 
[7] Wintjens R, Rooman M. Structural classification of HTH DNA-binding domains and protein-DNA interaction modes. Journal of Molecular Biology. 1996;262(2):294-313. DOI: 10.1006/jmbi.1996.0514. PMID 8831795

[8] Aravind L, Anantharaman V, Balaji S, Babu MM, Iyer LM. The many faces of the helixturn-helix domain: Transcription regulation and beyond. FEMS Microbiology Reviews. 2005;29(2):231-262. Review. PubMed PMID: 15808743

[9] Johnson DS, Mortazavi A, Myers RM, Wold B. Genome-wide mapping of in vivo proteinDNA interactions. Science. 2007;316:1497-1502

[10] Reece-Hoyes JS, Barutcu AR, McCord RP, Jeong JS, Jiang L, MacWilliams A, Yang X, Salehi-Ashtiani K, Hill DE, Blackshaw S, Zhu H, Dekker J, Walhout AJM. Yeast onehybrid assays for gene-centered human gene regulatory network mapping. Nature Methods. 2011;8:1050-1052

[11] Reece-Hoyes JS, Diallo A, Lajoie B, Kent A, Shrestha S, Kadreppa S, Pesyna C, Dekker J, Myers CL, Walhout AJ. Enhanced yeast one-hybrid assays for high-throughput genecentered regulatory network mapping. Nature Methods. 2011;8(12):1059-1064. DOI: 10.1038/nmeth.1748. PubMed PMID: 22037705; PubMed Central PMCID: PMC3235803

[12] ENCODE Project Consortium. An integrated encyclopedia of DNA elements in the human genome. Nature. 2012;489(7414):57-74. DOI: 10.1038/nature11247. PubMed PMID: 22955616; PubMed Central PMCID: PMC3439153

[13] Wingender E. The TRANSFAC project as an example of framework technology that supports the analysis of genomic regulation. Brief Bioinform. 2008 Jul;9(4):326-332. DOI: 10.1093/bib/bbn016. Epub 2008 Apr 24. PubMed PMID: 18436575

[14] Kolchanov NA, Ignatieva EV, Ananko EA, Podkolodnaya OA, Stepanenko IL, Merkulova TI, Pozdnyakov MA, Podkolodny NL, Naumochkin AN, Romashchenko AG. Transcription regulatory regions database (TRRD): Its status in 2002. Nucleic Acids Research. 2002; 30(1):312-317

[15] Zerbino DR, Johnson N, Juetteman T, Sheppard D, Wilder SP, Lavidas I, Nuhn M, Perry E, Raffaillac-Desfosses Q, Sobral D, Keefe D, Gräf S, Ahmed I, Kinsella R, Pritchard B, Brent S, Amode R, Parker A, Trevanion S, Birney E, Dunham I, Flicek P. Ensembl regulation resources. Database (Oxford). 2016 Feb 17;2016. pii: bav119. DOI: 10.1093/database/bav119. Print 2016. PubMed PMID: 26888907; PubMed Central PMCID: PMC4756621

[16] Liu ZP, Wu C, Miao H, Wu H. RegNetwork: An integrated database of transcriptional and post-transcriptional regulatory networks in human and mouse. Database (Oxford). 2015 Sep 30;2015. pii: bav095. DOI: 10.1093/database/bav095. Print 2015. PubMed PMID: 26424082; PubMed Central PMCID: PMC4589691

[17] Jiang C, Xuan Z, Zhao F, Zhang MQ. TRED: A transcriptional regulatory element database, new entries and other development. Nucleic Acids Research. 2007;35(Database issue):D137-D140. PubMed PMID: 17202159; PubMed Central PMCID: PMC1899102 
[18] TRRUST v2: An expanded reference database of human and mouse transcriptional regulatory interactions. Nucleic Acids Research; 26 Oct, 2017

[19] Lesurf R, Cotto KC, Wang G, Griffith M, Kasaian K, Jones SJM, Montgomery SB, Griffith OL, The Open Regulatory Annotation Consortium. ORegAnno 3.0: A community-driven resource for curated regulatory annotation. Nucleic Acids Research. 2016;44(D1):D126D132. DOI: 10.1093/nar/gkv1203

[20] Münch R, Hiller K, Barg H, Heldt D, Linz S, Wingender E, Jahn D. PRODORIC: Prokaryotic database of gene regulation. Nucleic Acids Research. 2003;31:266-269

[21] Yevshin IS, Sharipov RN, Valeev TF, Kel AE, Kolpakov FA. GTRD: A database of transcription factor binding sites identified by ChIP-seq experiments. Nucleic Acids Research. 2017;45(D1):D61-D67

[22] Wilson D, Charoensawan V, Kummerfeld SK, Teichmann SA. DBD-Taxonomically broad transcription factor predictions: New content and functionality. Nucleic Acids Research. 2008;36(suppl_1):D88-D92. DOI: 10.1093/nar/gkm964

[23] Lewis BP, Shih I-H, Jones-Rhoades MW, Bartel DP, Burge CB. Prediction of mammalian microRNA targets. Cell. 2003;115(7):787-798

[24] Brennecke J, Stark A, Russell RB, Cohen SM. Principles of microRNA-target recognition. PLoS Biology. 2005;3(3):e85

[25] Valinezhad Orang A, Safaralizadeh R, Kazemzadeh-Bavili M. Mechanisms of miRNAmediated gene regulation from common downregulation to mRNA-specific upregulation. International Journal of Genomics. 2014;2014:970607. DOI: 10.1155/2014/970607. Epub 2014 Aug 10. Review. PubMed PMID: 25180174; PubMed Central PMCID: PMC4142390

[26] Catalanotto C, Cogoni C, Zardo G. MicroRNA in control of gene expression: An overview of nuclear functions. International Journal of Molecular Sciences. 2016;17(10):pii: E1712. Review. PubMed PMID: 27754357; PubMed Central PMCID: PMC5085744

[27] Zeng Y, Yi R, Cullen BR. MicroRNAs and small interfering RNAs can inhibit mRNA expression by similar mechanisms. Proceedings of the National Academy of Sciences of the United States of America. 2003;100(17):9779-9784. Epub 2003 Aug 5. PubMed PMID: 12902540; PubMed Central PMCID: PMC187842

[28] Reinhart BJ, Slack FJ, Basson M, Pasquinelli AE, Bettinger JC, Rougvie AE, Horvitz HR, Ruvkun G. The 21-nucleotide let-7 RNA regulates developmental timing in Caenorhabditis elegans. Nature. 2000;403(6772):901-906. PubMed PMID: 10706289

[29] Llave C, Xie Z, Kasschau KD, Carrington JC. Cleavage of scarecrow-like mRNA targets directed by a class of Arabidopsis miRNA. Science. 2002;297(5589):2053-2056. PubMed PMID: 12242443

[30] Lee RC, Feinbaum RL, Ambros V. The C. Elegans heterochronic gene lin-4 encodes small RNAs with antisense complementarity to lin-14. Cell. 1993;75(5):843-854. PubMed PMID: 8252621 
[31] Place RF, Li LC, Pookot D, Noonan EJ, Dahiya R. MicroRNA-373 induces expression of genes with complementary promoter sequences. Proceedings of the National Academy of Sciences of the United States of America. 2008;105(5):1608-1613. DOI: 10.1073/pnas.0707594 105. Epub 2008 Jan 28. Erratum in: Proc Natl Acad Sci U S A. 2018 Mar 19;:. PubMed PMID: 18227514; PubMed Central PMCID: PMC2234192

[32] Kozomara A, Griffiths-Jones S. miRBase: Annotating high confidence microRNAs using deep sequencing data. Narrative. 2014;42:D68-D73

[33] Chou C-H, Shrestha S, Yang C-D, Chang N-W, Lin Y-L, Liao K-W, Huang W-C, Sun T-H, Tu S-J, Lee W-H, Chiew M-Y, Tai C-S, Wei T-Y, Tsai T-R, Huang H-T, Wang C-Y, Wu H-Y, Ho S-Y, Chen P-R, Chuang C-H, Hsieh P-J, Wu Y-S, Chen W-L, Li M-J, Wu Y-C, Huang XY, Ng FL, Buddhakosai W, Huang P-C, Lan K-C, Huang C-Y, Weng S-L, Cheng Y-N, Liang C, Hsu W-L, Huang H-D. miRTarBase update 2018: A resource for experimentally validated microRNA-target interactions. Nucleic Acids Research. 2018;46(D1):D296-D302. DOI: $10.1093 /$ nar/gkx1067

[34] Wong N, Wang X. miRDB: An online resource for microRNA target prediction and functional annotations. Nucleic Acids Research. 2015;43(D1):D146-D152

[35] Hsu SD, Chu CH, Tsou AP, Chen SJ, Chen HC, Hsu PW, Wong YH, Chen YH, Chen GH, Huang HD. miRNAMap 2.0: Genomic maps of microRNAs in metazoan genomes. Nucleic Acids Research. 2008;36(Database issue):D165-D169

[36] Li SC, Shiau CK, Lin WC. Vir-Mir db: Prediction of viral microRNA candidate hairpins. Nucleic Acids Res. 2008 Jan;36(Database issue):D184-D189. Epub 2007 Aug 15. PubMed PMID: 17702763; PubMed Central PMCID: PMC2238904

[37] Hsu PW, Lin LZ, Hsu SD, Hsu JB, Huang HD. ViTa: Prediction of host microRNAs targets on viruses. Nucleic Acids Research. 2007;35(Database issue):D381-D385

[38] Xiao F, Zuo Z, Cai G, Kang S, Gao X, Li T. miRecords: An integrated resource for microRNA-target interactions. Nucleic Acids Research. 2009;37:D105-D110

[39] Tokar T, Pastrello C, Rossos AEM, Abovsky M, Hauschild AC, Tsay M, Lu R, Jurisica I. mirDIP 4.1-integrative database of human microRNA target predictions. Nucleic Acids Research. 2018;46(D1):D360-D370. DOI: 10.1093/nar/gkx1144. PubMed PMID: 29194489; PubMed Central PMCID: PMC5753284

[40] Szymon M. Kiełbasa, Nils Blüthgen, Michael Fähling, Ralf Mrowka; Targetfinder.org: A resource for systematic discovery of transcription factor target genes, Nucleic Acids Research, 38, suppl 2, 2010, W233-W238, 10.1093/nar/gkq374

[41] Wang Z, Civelek M, Miller CL, Sheffield NC, Guertin MJ, Zang C. BART: A transcription factor prediction tool with query gene sets or epigenomic profiles. Bioinformatics. 2018 Mar 28. DOI: 10.1093/bioinformatics/bty194. [Epub ahead of print] PubMed PMID: 29608647 
[42] Kel AE, Goessling E, Reuter I, Cheremushkin E, Kel-Margoulis OV, Wingender E. Match (TM): A tool for searching transcription factor binding sites in DNA sequences. Nucleic Acids Research. 2003;31:3576-3579

[43] Marc R, Steffen P, Hoechsmann M, Giegerich R. Fast and effective prediction of microRNA/ target duplexes RNA. RNA. 2004

[44] Agarwal V, Bell GW, Nam JW, Bartel DP. Predicting effective microRNA target sites in mammalian mRNAs. Elife. 2015 Aug 12;4. DOI: 10.7554/eLife.05005. PubMed PMID: 26267216; PubMed Central PMCID: PMC4532895

[45] Dweep $\mathrm{H}$ et al. miRWalk-Database: Prediction of possible miRNA binding sites by 'walking' the genes of 3 genomes. Journal of Biomedical Informatics. 2011;44:839-837

[46] Friard O, Re A, Taverna D, De Bortoli M, Corá D. CircuitsDB: A database of mixed microRNA/transcription factor feed-forward regulatory circuits in human and mouse. BMC Bioinformatics. 2010;11:435. DOI: 10.1186/1471-2105-11-435. PubMed PMID: 20731828; PubMed Central PMCID: PMC2936401

[47] Wang H, Luo J, Liu C, Niu H, Wang J, Liu Q, Zhao Z, Xu H, Ding Y, Sun J, Zhang Q. Investigating microRNA and transcription factor co-regulatory networks in colorectal cancer. BMC Bioinformatics. 2017;18(1):388. DOI: 10.1186/s12859-017-1796-4. PubMed PMID: 28865443; PubMed Central PMCID: PMC5581471

[48] Nampoothiri SS, Fayaz SM, Rajanikant GK. A novel five-node feed-forward loop unravels miRNA-gene-TF regulatory relationships in ischemic stroke. Molecular Neurobiology. 2018. DOI: 10.1007/s12035-018-0963-6. [Epub ahead of print] PubMed PMID: 29524052

[49] Simsek D, Tiu GC, Flynn RA, Byeon GW, Leppek K, Xu AF, Chang HY, Barna M. The mammalian ribo-interactome reveals ribosome functional diversity and heterogeneity. Cell. 2017;169(6):1051-1065.e18. DOI: 10.1016/j.cell.2017.05.022. PubMed PMID: 28575669; PubMed Central PMCID: PMC5548193 